\title{
Disrupting Family Group Conference practice in Aotearoa New Zealand: A learning project
}

Raewyn Nordstrom (Ngāti Hine, Rongomaiwahine, Ngāti Whakaue and Tainui) and

Deb Stanfield, Independent Practitioner

\begin{abstract}
Participation in, or facilitation of, Family Group Conferences (FGCs) and hui-ā-whānau (family meetings) are key social work practice activities in Aotearoa New Zealand. Social work students are expected to graduate with the cultural competence necessary to work ethically with whannau Māori according to the bicultural practice principles of Te Tiriti ō Waitangi. This competence includes skills in the facilitation of joint decision making, shared responsibility and the use of Māori engagement principles, all of which are fundamental to the traditional and professional practice of hui (meetings).
\end{abstract}

We argue that, for social work students to enter the profession with the ability to work effectively in a statutory setting, and with whānau Māori, learning must go beyond the processes of the FGC as set out in the Oranga Tamariki Act (1989)—originally the Children, Young Persons and Their Families Act, 1989-and embrace the historical and cultural intent of this practice. It must encourage students to be mindful of their cultural selves in the process and to reflect on the tensions arising from how the FGC sits within a statutory, managerial, and neoliberal policy framework. This article applies concepts of Māori and Western pedagogy to a learning strategy developed by the authors over a period of four years. The Reality FGC Project began as a way of assisting students to develop skills and apply theory to practice, and unexpectedly became an opportunity to reflexively and iteratively consider the role of social work education in rethinking FGC practice in Aotearoa New Zealand.

Keywords: Family Group Conference; social work education; interprofessional education; integrated learning; critical reflection; Pūao-te-Āta-tū

AOTEAROA

NEW ZEALAND SOCIAL WORK 33(4), 82-88.

CORRESPONDENCE TO: Deb Stanfield

Stanfield.deb@gmail.com
Ngā hiahia kia tītiro ki te tīmatatanga, a, ka kite ai tātou te mutunga

(You must understand the beginning if you wish to see the end)

\section{Introducing the authors}

Raewyn Nordstrom facilitated the first Family Group Conference (FGC) in Aotearoa New Zealand after the Oranga Tamariki Act (formerly the Children Young Persons and
Their Families Act) was passed in 1989 and continued in her role as FGC coordinator in Kirikiriroa (Hamilton), Aotearoa New Zealand until she retired in 2019. The considers herself a Native Disruptor of Ngāti Hine, Rongomaiwahine, Ngāti Whakaue and Tainui descent.

Deb Stanfield is a social worker with child protection, social work education and supervision experience in Aotearoa New Zealand. Nō Yorkshire ōku mātua. Nō 
Montréal, Canada ahau. E noho ana mātou ko tōku whānau ki Te Kawa.

This article refers to a recorded conversation between the authors, in which Raewyn, who facilitated the first FGC in Aotearoa (and in the world), reflects on 30 years of coordinating FGCs (available via podcast).

The aim of this article is to describe an FGC learning project created for social work students in Aotearoa New Zealand, and to rationalise it using Māori and Western concepts of adult learning and Ako (higher learning). The FGC is an intervention enshrined in New Zealand's child protection legislation, the Oranga Tamariki Act (1989)_ hereafter OT Act—and designed to ensure shared decision making and responsibility on behalf of mokopuna (child/children) and rangatahi (young people). The Reality FGC project, which involves students in a simulated FGC (using role play), provides opportunity for them to prepare for the experience, to actively engage in it, and then to critically reflect on it. It is argued that learning about the FGC in this context serves to develop critical practice skills, and to reinforce the "spirit" of the FGC as inspired by P $\bar{u} a o-t e-\bar{A} t a-t \bar{u}$ (1986) and subsequently intended by the OT Act (1989).

We reference a podcast created by the authors in which Raewyn, who facilitated the first FGC in Aotearoa and, in fact, the world, remembers the important development of Pūao-te-Āta-tū (1986), and the golden promise of the early days. The intention of the podcast was to contribute to the archives an historical account of the FGC.

\section{Background-the FGC}

The FGC is promoted as a whānau-led, decision-making forum inspired by the concept of whānau rangatiratanga (whānau decision-making and voice) and reflecting traditional Māori whānau problem-solving methods. It was formally incorporated in the OT Act (1989) as a direct response to the recommendations of Pūao-te-Ātatū (Day Break) released in 1988 by the Ministerial Advisory Committee on a Māori Perspective (Department of Social Welfare). This document provided evidence that the then Department of Social Welfare was institutionally racist, and solutions were put forward to change this, including that Māori be actively and meaningfully involved in decision making about their mokopuna and rangatahi. The Pūao-te-Āta-tū Report (1986) is generally accepted in Aotearoa New Zealand as pivotal to the re-visioning of social work for Māori social workers, and for social work with whānau Māori (Hollis-English, 2012).

The FGC is a hui (meeting) with the legal mandate of planning for the safety of children and young people who are at risk of abuse, and involves family, whānau, and professionals who have a relationship with the child or young person. Social workers, the police, or any other organisation with concerns about the safety of mokopuna or rangatahi (deemed in need of "care and protection") can make a referral for an FGC under any of the grounds contained in s14(1) of the OT Act (1989). These grounds include concerns about child physical, sexual and / or emotional abuse, and neglect. There are also FGCs held related to youth justice processes, which have the additional focus of attending to what is behind the young person's offending, how they can take responsibility for this offending and how reparation can be made to the victim. Although the FGC was formalised in the OT Act 1989, it is recognised that social workers applied informal methods of whānau resolution and decision-making long before this (Hyslop, in press).

It is a commonly accepted in Aotearoa New Zealand that the original intent of the FGC has become eroded in a neoliberal, largely managerial social service environment to the detriment of children and families in Aotearoa New Zealand (Hyslop, in press; Moyle, 2014; Moyle \& Tauri, 2016; Sharples, 2008; Tauri, 2015). There is a problematic tension between the family support and 
child protection mandates of the FGC process (Connolly, 2006).

The purpose of the FGC is to give family opportunity to propose a plan for the safety of children, however the authority for these plans remains with the statutory social worker, and the judicial system. However, it is preferred that issues are resolved informally without resorting to a more formal FGC. FGCs were reported as being oppressive and predetermined, rather than empowering, processes (Hyslop, in press, p. 169).

Raewyn convened more than 3500 FGCs over thirty years and can recall many of the whannau by name and outcome. In our podcast conversation (Nordstrom \& Stanfield, 2019), she remembers a challenge from a kaumatua (respected elder) about the notion of whānau decision making, and how she, in turn, challenged managers to support ideas brought forward by whānau and families. Raewyn comments on the challenges for wahine Māori (Māori women) in this role and the "creative native disrupting" skills needed to assert the rights and needs of mokopuna and whānau. Her stories also highlight her role in providing consistency for whānau and her colleagues over the many social, legislative, policy and management changes of the last three decades.

\section{Context and rationale}

The course relevant to this project began as a child protection elective, designed for a range of social and health care students (social work, counselling, nursing, midwifery), and partly in response to directives of the White Paper for Vulnerable Children (Ministry for Social Development, 2012), mandating that all professionals working with children develop child protection knowledge and skills. The course included basic information about child abuse, child protection frameworks, and supported development of practice skills, including collaborative working, group facilitation and conflict-resolution skills. It was envisaged that, by using an interprofessional education approach, students would gain skills in working collaboratively.

It was also expected that by using reflective practice methods, including the transformational Takepu-principled approach to learning (Pohatu, 2013), students would be attentive and responsive to their own world views, cultural perspectives, and personal experiences relevant to child abuse. They would develop the ability to think critically, to "read one's world more deeply and ask meaningful 'why' questions" (Akhter \& Leonard, 2014, p. 95). Ngā takepū is one part of the wider kaupapa wānanga framework accompanied by $n g \bar{a} \bar{u} a r a$ (values) and $n g \bar{a}$ huang $\bar{a}$ (attributes) (Pohatu, 2011).

Regardless of the context of their work, social workers and other human service professionals are frequently involved as professional members of FGCs; it can be a complex process, often emotionally fraught, and its success depends on a high level of professional skill and understanding. It is the shared opinion of the authors that there is specific value in introducing students to the FGC; it provides a non-threatening insight into its history, including the role of colonisation, structure and process, an opportunity to explore the myths and politics surrounding it, and the development of the necessary practice skills.

\section{Learning principles}

Recent Aotearoa New Zealand literature about social work education incorporates key adult learning principles, specifically those of experiential learning (Marlowe et al., 2015), integrated learning (Gibbons \& Gray, 2002), reflective learning (Adamson, 2011; Tsuruda \& Shepherd, 2016), and Takepūprincipled learning (Pohatu, 2013), all of which support development of reflective and critical practice, or whaiwakaaro, a professional competency requirement (Social Workers Registration Board [SWRB], 2015). 
These approaches are sourced primarily from indigenous, constructivist and humanistic learning theories; for example, the "communities of practice" situated learning concept (Wenger, 2006), reflective learning (Schön, 1987), transformative learning (Mezirow, 1991), and critical reflection (Brookfield, 2009).

The Takepū (principles) framework (Pohatu, 2011, 2013), provides what the author refers to as "signposts" to guide critical reflection, which aspires to transformational learning. It supports students to develop awareness of who they are, to become closer to their cultural and spiritual principles and identities. There is recognised value in sharing stories and engaging in dialogue which develops awareness of multiple contexts and dismantles assumptions. There is particular focus on the various outcomes of historical processes, for example colonisation (Akhter, 2015).

Stewart (2013) provides practical applications of a variety of adult learning theories to classroom activities. For example, social and situated learning such as that proposed by Lave and Wenger (1991), "emphasize the value of social interaction in expanding understandings and transferring learning across contexts... providing opportunity to apply learning from the closed world of the campus to the real world" (Stewart, 2013, p. 14). This theory supports how the Reality FGC experience influences learning, suggesting that it assists students to become active participants in their potential communities of practice, to overcome barriers to belonging in that community, and to begin developing an identity in that community. Although the students are role playing a simulated scenario, they are engaging on location with practitioners, and experience the nervousness, excitement, and performance anxiety not dissimilar to the "real thing." The purpose of this is, as Lave and Wenger said, "not to learn from talk but to learn to talk" (cited in Stewart, 2013, p. 14).
It is accepted in the field of social work education that practical/practicum experiences are pivotal in assisting students to integrate theory with practice (Marlowe et al., 2015). This experiential mode of learning offers opportunity to develop deeper reflective awareness because of challenges to beliefs, hegemonic assumptions and perceptions that come about when faced with professional tensions and dilemmas. The Reality FGC activity offers a "fieldlike" experience in a snapshot which can then be actively reflected upon as a group in a classroom setting and/or immediately reflected upon personally in an online environment. It essentially provides a practice upon which students can reflect, which is a challenge in tertiary settings, and which enables reflective learning to be supported by the tutor. "Schön argued for a step beyond simply matching classroom problems to textbook theories; the practitioner is required to call heavily on professional experience to construct solutions on-demand to unique situations" (Stewart, 2013, p. 16).

And lastly, social work education incorporates ideas of integrated learning, where "the role of the teacher as facilitator is to assist learners to make links between different kinds of experience and to make connections between areas of knowledge" (Gibbons \& Gray, 2002, p. 532). The FGC is underpinned by theoretical, cultural, and historical knowledge, and drawing links between these areas of knowledge, while experiencing the FGC process results in a more powerful, integrated learning experience. It is acknowledged that the emotional and relational aspects of experience can create barriers to gaining new knowledge or can distort meaning. An educator using an integrated approach would take the opportunity to "challenge interpretations of experience and to foster this process in the group environment" (Gibbons \& Gray, 2002, p. 532).

In summary, this project is an experiential learning activity that relies on student 
participation in a simulated activity, draws on community resources and knowledge, links experienced practitioner knowledge with student learning and provides a realistic social work environment and scenario within which to learn practical and reflective skills. The opportunity offered to students parallels, as closely as possible, that which they will experience in practice. A combination of learning theories is employed to maximise potential learning that can come of the opportunity, in this case the Reality FGC.

\section{The learning partnership}

The Reality FGC is supported by a partnership between Tangata Whenua (Māori) and Tangata Tiriti (non-Māori) practitioners. It was the authors' hope and intention for students to witness a professional relationship that mirrors bicultural or Treatybased best practice-that of respect and trust built over time- - prior to the commencement of the project. The relationship between professional and community tertiary educators also offers opportunity for community-building and professional development (Gibbons \& Gray, 2002).

The practitioner and the educator hold distinct roles in this collaboration. The practitioner manages the practice experience by actively convening an FGC in a way that most closely resembles their everyday work. The educator provides the background knowledge, sets up a reflective environment, and acts as an observer throughout the conference, collecting points of potential learning, and ensuring the well-being of participants. Both practitioner and educator prepare for the conference together, including the development and refinement of a case study to best reflect situations common to current, local practice, paying attention to the cultural and ethical factors related to this, and which is most conducive to the unique learning needs of the group.

For example, the practitioner suggests which family members should be present, which professionals might attend, and what support might be needed for vulnerable family members. Prior to the conference, the practitioner arranges for the family groups to be met with separately to prepare them for the conference. This includes assisting the students to assume their roles, understand their rights, express how they, as whānau, may be feeling and subsequently behaving, and to ensure all members feel safe and supported (Nordstrom \& Stanfield, 2019). This practice parallels the type of preparation conducted alongside whānau.

Meanwhile, the educator has facilitated learning about the cultural history of the family group conference, its intention, its place in legislation and the challenges inherent in its practice. A reflective and critical learning environment is established, as described earlier in this article, with the aim of enabling students to think deeply, to focus on who they are (Ko wai au?), to examine assumptions and power dynamics. A podcast created by the authors, which offers both an example of a reflective conversation and a recorded history of the FGC, adds to this kete (basket) of teaching resources (Nordstrom \& Stanfield, 2019).

Reality FGC conferences have so far been held in the offices of Oranga Tamariki. Although in practice whānau are typically offered a choice of venue (for example, on Marae, community houses, homes, or church settings), this has been a practical choice for student learning given proximity to the campus and availability of space for large numbers of students. The suitability of the venue is an ongoing conversation, mirroring that which occurs in practice, and is another example of the parallels between social work practice and social work education which the students can be involved in and learn from.

The FGC coordinator/practitioner creates a group environment that follows principles of tikanga (Māori customary practices) and whakawhanaungatanga (the process of establishing relationships). They 
communicate the need for unconditional respect. As Raewyn says in the podcast, regardless of who we are or what we've done, "We are all equal, there is no hierarchy, no one is more or less important" (Nordstrom \& Stanfield, 2019). Clear ground rules about behaviour are laid, the emotions and difficulties of participating in the process are acknowledged, and skills are used to ensure everyone has an opportunity to speak and be heard. The practitioner respectfully and firmly manages behaviour that breaks tikanga and uses appropriate cultural skills to engage and support whānau, ensuring a sense of belonging and trust. They maintain a key focus on mokopuna as central to the hui, and are clear with those students, especially those playing the professional roles that they speak to family rather than about them. The plan developed from the conference is clear and "smart," and connected to the wishes, capacity and rights of whānau.

After the FGC is held, the educator provides a reflective space to recall the experience of the FGC, to understand more deeply the emotions felt, to make sense of what unfolded. Students are assisted to contextualise the experience within the social work skills, principles, practice and structural issues, and the history of colonisation introduced prior to the event. Reflection and dialogue prompt thinking about belief systems, self-awareness, and healing, thereby creating opportunity for mindsets to be transformed (Akhter, 2016).

\section{Summary}

This article has described the Reality FGC project and considered it in the context of adult and higher learning principles, and flexible learning approaches. Practical applications of Ngā Takepū and humanistic theories of student learning (which include reflection and transformative learning) emphasise developing skills in "metacognition," support for self-directed learning and a critical awareness of the multiple ways people experience the world.
The practical application of situated learning includes "developing organizational awareness by providing opportunities for peripheral forms of engagement with professional communities" (Stewart, 2013, pp. 14). This is a feature of the Reality FGC project and can be further developed by incorporating other applications suggested within this learning theory. For example, the use of wānanga ipurangi (online collaborative tools) that includes practitioners, has the potential to increase the learning and community building opportunities for social work students.

Finally, although there is international research about FGCs (and their relationship to the restorative justice movement) (Connolly, 2006), there is little research on the effectiveness of FGCs in Aotearoa (Kanyi, 2013). There has been robust criticism of FGC delivery in Aotearoa New Zealand, their effectiveness, and their purpose:

Family group conferencing in our court has gone a bit astray, too many lawyers and such involved. They have lost the plot from where we had it, where it is just community and people talking to each other in a Māori format. Very easy, very simple! It works because we cannot talk past each other. We are there identifying what needs to be done. (Sharples, 2008, p. 51)

There is ongoing, widespread condemnation of child protection and youth justice services in Aotearoa with several government-led and independent practice reviews over the last three years, and the key messages of Pūao-te-Āta-tū continue to be referenced in this space (Boulton et al., 2020). Students must be connected to this analysis, be supported to envision a role for themselves in responding to it, and to find ways of promoting genuine trust in whānau decisionmaking and autonomy.

Accepted 28 November 2021

Published 23 December 2021 


\section{References}

Adamson, C. (2011). Getting the balance right: Critical reflection, knowledge and the social work curriculum. Advances in Social Work \& Welfare Education, 13(1), 22-34.

Akhter, S., \& Leonard, R. (2014). Takepū principled approach: A new vision for teaching social work practice in Aotearoa New Zealand. In J. Duke, M. Henrickson, \& E. Beddoe (Eds.), Protecting the public Enhancing the profession (pp. 93-104). Social Workers Registration Board. https://www.researchbank.ac.nz/ bitstream/handle/10652/3151/SWRB-PPEP-conferenceproceedings. . pdf? sequence $=1$ \&isAllowed $=y$

Akhter, S. (2015). Reimagining teaching as a social work educator: A critical reflection. Advances in Social Work and Welfare Education, 17(1), 39-51.

Boulton, A., Levy, M., \& Cvitanovic, L. (2020). Beyond Pūao-te-Āta-tū: Realising the promise of a new day. Te Arohahi Series paper (December 2020-06). Nga Pae o te Maramatanga. http://www.maramatanga.ac.nz/sites/ default/files/teArotahi_20-1106.pdf

Brookfield, S. (2009). The concept of critical reflection: Promises and contradictions. European Journal of Social Work, 12(3), 293-304. https://doi:10.1080/13691450902945215

Connolly, M. (2006). Fifteen years of family group conferencing: Coordinators talk about their experiences in Aotearoa New Zealand. British Journal of Social Work, 36(4), 523-540.

Gibbons, J., \& Gray, M. (2002). An integrated and experience-based approach to social work education: The Newcastle model. Social Work Education: The International Journal, 21(5), 529-549.

Hollis-English, A. (2012). Pūao-te-Āta-tū: Informing Māori social work since 1986. Aotearoa New Zealand Social Work, 24(3/4), 41-48.

Hyslop, I. (in press). A political history of child protection: Lessons for reform from Aotearoa New Zealand. Bristol University Press. ISBN 978 1-4473- 5318-8

Kanyi, T. (2013). Lack of outcome research on New Zealand care and protection family group conference. Aotearoa New Zealand Social Work, 25(1), 35-42. https://anzasw.nz/wp-content/uploads/SWR-Issue-XXVNumber-31-Articles-Kanyi.pdf

Lave, J., \& Wenger, E. (1991). Situated learning: Legitimate peripheral participation. Cambridge University Press.

Māori Perspective Advisory Committee. (1988). Pūao-te-Ātatū (Day Break): The report of the Ministerial Advisory Committee on a Māori Perspective for the Department of Social Welfare. Department of Social Welfare, Wellington. http://www.msd.govt.nz/documents/aboutmsd-and-our-work/publications-resources/archive/1988puaoteatatu.pdf

Marlowe, J., Appleton, C., Chinnery, S., \& Van Stratum, S. (2015). The integration of personal and professional selves: Developing students' critical awareness in socia work practice. Social Work Education: The International Journal, 34(1), 60-73. https://doi:10.1080/02615479.20 14.949230

Mezirow, J. (1991). Transformative dimensions of adult learning. Jossey-Bass.
Ministry for Social Development. (2012). The White Paper for Vulnerable Children. New Zealand Government. http://www.childrensactionplan.govt.nz/action-plan/whitepaper/

Moyle, P. (2014). Māori social workers' experiences of care and protection: A selection of findings. Aotearoa New Zealand Social Work, 26(1), 55-64.

Moyle, P., \& Tauri, J. (2016). Māori, family group conferencing and the mystifications of restorative justice. Victims \& Offenders, 11(1), 87-106. https://doi:10.1080/ 15564886.2015.1135496

Nordstrom. R., \& Stanfield, D. (2019, October 27). Thirty years of the family group conference: In conversation with Raewyn Nordstrom [Audio podcast]. Reimagining Social Work in Aotearoa New Zealand. http://www.reimaginingsocialwork.nz/2019/10/thirtyyears-of-the-family-group-conference-in-conversationwith-raewyn-nordstrom/

Pohatu, W. T. (2011). He ara tohu: Signposting a way. Toroa-te Nukuroa, TeWānangā o Aotearoa, 6, 8-17. https://ndhadeliver.natlib.govt.nz/delivery/ DeliveryManagerServlet?dps_pid=IE14660090

Pohatu, T. W. (2013). Āta: Growing respectful relationships. Ata: Journal of Psychotherapy Aotearoa New Zealand, 17(1), 13-26.

Schön, D. A. (1987). Educating the reflective practitioner. Jossey-Bass.

Sharples, P. (2008). Te Whānau Āwhina: A Māori model of restorative justice for the world (pp. 46-52). Proceedings of the Traditional Knowledge Conference Te Tatau Pounamu: The Greenstone Door: Traditional Knowledge and Gateways to Balanced Relationships, Auckland, New Zealand. Ngā Pae o te Māramatanga. http://www.maramatanga.co.nz/sites/default/files/TC2008.pdf

Social Workers Registration Board. (2015). The SWRB ten core competence standards. https://swrb.govt.nz/forsocial-workers/core-competence-standards/

Stewart, M. (2013). Understanding learning: Theories and critique. In L. Hunt \& D. Chalmers (Eds.), University teaching in focus: A learning approach (pp. 3-20) Routledge.

Tauri, J. (2015). "Beware justice advocates bearing gifts": A commentary on the glorification of family group conferencing [Book review]. New Zealand Sociology, 30(1), 183-190.

Tsuruda, S., \& Shepherd, M. (2016). Reflective practice: Building a culturally responsive pedagogical framework to facilitate safe bicultural learning. Advances in Social Work \& Welfare Education, 18(1), 23-38.

Wenger, E. (2006). Communities of practice, a brief introduction. http://www.ewenger.com/theory/ communities_of_practice_intro.htm 